\title{
ANALISIS BUTIR SOAL UJIAN AKHIR MATA PELAJARAN AKUNTANSI KEUANGAN MENGGUNAKAN MICROSOFT OFFICE EXCEL 2010
}

\section{ANALYSIS OF FINAL EXAM QUESTIONS IN FINANCIAL ACCOUNTING USING MICROSOFT EXCEL 2010}

\author{
Oleh: \\ Muslikah Purwanti \\ Pendidikan Akuntansi Universitas Negeri Yogyakarta \\ luph.gandi@yahoo.co.id
}

\begin{abstract}
Abstrak
Penelitian ini bertujuan untuk mengetahui kualitas soal ujian akhir mata pelajaran akuntansi keuangan menggunakan Microsoft Office Excel 2010 di SMK Negeri 1 Yogyakarta tahun ajaran 2013/2014. Penelitian ini merupakan penelitian deskriptif dengan menggunakan pendekatan kuantitatif. Hasil penelitian menunjukkan bahwa: (1)butir soal pilihan ganda valid 19 butir $(63,33 \%)$, soal tidak valid 11 butir (36,67\%), soal uraian valid 3 butir (75\%), tidak valid 1 butir (25\%); (2)soal pilihan ganda indeks reliabilitas menunjukkan angka 0,660, uraian sebesar 0,50 sehingga tidak reliabel; (3)bentuk soal pilihan ganda 4 butir $(13,33 \%)$ kategori sukar, 9 butir soal (30\%) sedang, dan 16 butir $(56,67 \%)$ mudah, bentuk soal uraian 4 butir (100\%) kategori soal tingkat kesulitan sedang; (4)butir soal pilihan ganda dengan daya pembeda jelek 7 butir (23,33\%), cukup 7 butir $(23,33 \%)$, baik 10 butir (33,33\%), baik sekali 6 butir (20\%), bentuk soal uraian dengan daya pembeda jelek 1 butir (25\%), cukup 1 (25\%), dan baik sekali 2 butir (50\%); (5)bentuk soal pilihan ganda yang termasuk soal dengan pengecoh atau distractor yang berkualitas 3 butir (10\%) memiliki pengecoh sangat baik, 10 butir (33,33\%) baik, 11 butir (36,67\%) cukup, 4 butir (13,33\%) kurang baik, dan 2 butir $(6,67 \%)$ tidak baik.
\end{abstract}

Kata kunci: Analisis Butir Soal, SMK Negeri 1 Yogyakarta, Akuntansi Keuangan

\section{Abstract}

The aim of this research is to find out the quality of the final exam questions of Financial Accounting in SMK Negeri 1 Yogyakarta 2013/2014 using Microsoft Office Excel 2010. This research belongs to descriptive research which is using quantitative approach. The result has shown that:(1) there are 19 (63.33\%) questions which are valid and 11 (36.67\%) are invalid on the multiple choice questions. While on the essay questions, there are $3(75 \%)$ valid questions and 1 (25\%) invalid questions;(2) The multiple choice question shows the reliability index of 0.660, while the essay question shows 0.50 of reliability index. Therefore, they are considered not reliable;(3) There are 4 (13.33\%) difficult questions, 9 (30\%) moderate questions, and 16 (56.67\%) easy multiple choice questions. On the essay, according to the degree of difficulty, there are $4(100 \%)$ moderate questions; (4) According to the differential capacity, on the multiple choice, 7 (23.33\%) are categorized as poor, $7(23.33 \%)$ are sufficient, $10(33.33 \%)$ are good, and $6(20 \%)$ are excellent. And then on the essay, 1 $(25 \%)$ is poor, $1(25 \%)$ is sufficient, 2 (25\%) are excellent; (5) According to their distracter quality, on the multiple choice questions, 3 (10\%) having excellent, 10 (33.33\%) having good, 11 (36.67\%) having adequate, 4 (13.33\%) having unfavorable, and 2 (6.67\%) having poor distracters.

Keywords: Questions Analysis, SMK Negeri 1 Yogyakarta, Financial Accounting 


\section{PENDAHULUAN}

Pendidikan adalah investasi sumber daya manusia jangka panjang yang mempunyai nilai strategis bagi kelangsungan peradaban manusia di dunia. Oleh sebab itu, hampir semua negara menempatkan pendidikan sebagai sesuatu yang penting dan utama dalam konteks pembangunan bangsa dan negara. Seperti halnya bangsa Indonesia menempatkan pendidikan sebagai sesuatu yang penting dan utama. Hal ini dapat dilihat dari isi Pembukaan UUD 1945 alinea IV yang menegaskan bahwa salah satu tujuan nasional bangsa Indonesia adalah mencerdaskan kehidupan bangsa.

Salah satu faktor utama yang menentukan mutu pendidikan adalah guru. Guru yang berada di posisi terdepan dalam menciptakan kualitas sumber daya manusia. Guru yang berhadapan langsung dengan siswa di kelas melalui proses belajar mengajar. Di tangan gurulah akan dihasilkan siswa yang berkualitas, baik secara akademis, keahlian (skill), kematangan emosional, moral dan spiritual yang pada akhirnya akan menghasilkan generasi masa depan yang siap hidup dengan tantangan zamannya. Oleh karena itu, guru harus mempunyai kualifikasi, kompetensi, dedikasi tinggi dalam menjalankan tugas profesionalnya. Pada dasarnya keberhasilan pengajaran tidak hanya dapat dilihat dari hasil belajar yang dicapai oleh siswa, tetapi juga dari segi prosesnya. Guru adalah seorang yang paling bertanggung jawab atas hasilnya. Dengan demikian, guru wajib dibekali dengan evaluasi sebagai ilmu yang mendukung tugasnya, yakni mengevaluasi hasil belajar siswa.

Pencapaian tingkat pendidikan dapat dilihat melalui proses evaluasi. Evaluasi adalah kegiatan pengumpulan data untuk mengukur sejauh mana tujuan sudah tercapai (Suharsimi, 2009: 25). Dalam melakukan evaluasi, terdapat pengukuran dan penilaian. Pengukuran merupakan membandingkan sesuatu dengan satu ukuran. Penilaian merupakan mengambil suatu keputusan terhadap sesuatu dengan ukuran baik buruk. Terdapat dua teknik dalam mengevaluasi hasil belajar siswa di sekolah yaitu evaluasi dengan teknik tes dan teknik non-tes.

Tes merupakan alat ukur yang paling sering digunakan guru untuk mengukur hasil belajar siswa. Guru dapat mengetahui sejauh mana tujuan yang telah ditetapkan dapat tercapai dari hasil tes yang telah didapatkan. Oleh karena itu, agar tes dapat mengukur hasil dengan tepat, tes harus dikembangkan dengan benar. Tes baru akan berarti bila terdiri dari butir-butir soal yang menguji tujuan penting dan mewakili seluruh bahan yang diujikan.

Menurut Suharsimi (2009: 57) sebuah tes dapat dikatakan baik sebagai alat pengukur harus memenuhi persyaratan tes, yaitu memiliki validitas, reliabilitas, objektivitas, praktibilitas, dan ekonomis. Sebuah tes dikatakan valid apabila tes dapat tepat mengukur sesuatu yang akan diukur. Sebuah tes dikatakan reliabel apabila hasil-hasil tes menunjukkan ketetapan. Tes bersifat objektif berarti dalam melaksanakan tes tidak ada faktor subjektif yang mempengaruhi. Tes dikatakan memiliki praktibilitas tinggi apabila tes tersebut bersifat praktis yaitu: mudah dilaksanakan, mudah pemeriksaannya serta dilengkapi dengan petunjuk-petunjuk yang jelas. Ekonomis dalam melaksanakan tes berarti tidak membutuhkan biaya yang mahal, tenaga yang banyak, dan waktu yang lama. Berdasarkan pernyataan Suharsimi Arikunto tersebut, perlu diadakan proses analisis kualitas tes untuk mengetahui sejauh mana sebuah tes sudah dikatakan baik.

Analisis kualitas tes merupakan tahap yang harus ditempuh untuk mengetahui derajat kualitas suatu tes, baik tes secara keseluruhan maupun butir soal yang menjadi bagian tes. Analisis butir 
soal atau analisis item merupakan pengkajian pertanyaan-pertanyaan tes agar diperoleh perangkat pertanyaan yang memiliki kualitas yang memadai (Nana Sudjana, 2012: 135). Analisis soal antara lain bertujuan untuk mengadakan identifikasi soal-soal yang baik, kurang baik, dan soal yang jelek. Hal ini dapat dilakukan dengan menghitung beberapa aspek yaitu validitas, reliabilitas, tingkat kesukaran, daya pembeda dan pola sebaran jawaban.

Salah satu jenis tes yang harus dianalisis adalah tes sumatif. Tes ini merupakan tes yang dilaksanakan pada akhir unit program, yaitu akhir catur wulan, akhir semester, dan akhir tahun ajaran. Suharsimi Arikunto (2009: 38) menjelaskan bahwa evaluasi sumatif dilaksanakan setelah berakhirnya pemberian sekelompok program atau sebuah program yang lebih besar. Tujuan dari tes ini adalah untuk melihat hasil yang dicapai para siswa, yakni seberapa jauh tujuan-tujuan pembelajaran telah dikuasai siswa. Tes sumatif ini bermanfaat untuk menentukan nilai, untuk menentukan seorang siswa dapat atau tidaknya mengikuti kelompok dalam menerima program berikutnya, dan untuk mengisi catatan kemajuan belajar siswa yang berguna bagi orang tua siswa, pihak bimbingan dan penyuluhan di sekolah, pihak-pihak lain apabila siswa akan pindah sekolah atau memasuki lapangan pekerjaan. Tes sumatif terdiri dari tes objektif dan tes subjektif yang berbentuk uraian. Tes objektif yang digunakan adalah tes pilihan ganda (multiple choice test) yaitu tes yang terdiri atas suatu keterangan atau pemberitahuan tentang sesuatu yang belum lengkap, dan untuk melengkapi harus memilih salah satu dari beberapa kemungkinan jawaban atau alternatif jawaban yang telah disediakan. Serta tes subjektif yang digunakan berbentuk uraian, sejenis tes yang menuntut siswa untuk menguraikan dan menyatakan jawaban dengan kata-katanya dalam bentuk, teknik, dan gaya yang berbeda satu dengan yang lain.

Pada hasil wawancara yang telah dilakukan pada 25 Juli 2013, diketahui bahwa guru dalam membuat perangkat tes masih mengacu pada soal yang belum teruji kualitasnya, tidak melakukan kegiatan analisis butir soal terhadap soal buatannya sendiri dikarenakan proses analisis yang cukup rumit dan memerlukan waktu yang cukup lama. Guru hanya menganalisis secara manual untuk mengetahui tingkat kesukaran berdasarkan pola jawaban benar salah siswa sehingga belum teruji kualitas soalnya. Dengan demikian, belum diketahui mana soal yang baik, kurang baik, dan jelek berdasarkan validitas, reliabilitas, daya pembeda, tingkat kesukaran, serta pola sebaran jawaban di setiap butir soalnya.

Penelitian ini menggunakan program Microsoft Office Excel 2010. Analisis menggunakan program Microsoft Office Excel 2010 lebih memudahkan guru dalam melakukan analisis, karena hasil analisis lebih mudah dipahami sehingga akan lebih membantu. Penggunaan program Microsoft Office Excel 2010 biasanya sudah secara langsung terinstal, program dibuat dengan Microsoft Office Excel 2003 yang sudah umum digunakan, langkah pertama secara langsung mengisi jawaban peserta didik pada kolom yang tersedia (tidak perlu benar $=1$, salah $=0$ ), jika terjadi kesalahan dalam pengetikan jawaban siswa maka pada kolom status akan muncul keterangan dan peringatan sesuai kesalahan (lebih/kurang). Pada daftar hasil ujian dilengkapi dengan skor (salah, benar, jumlah skor), nilai ujian, dan ketercapaian peserta didik (terlampaui, tercapai, tidak tercapai). Analisis butir soal dilengkapi dengan indek daya pembeda (DP) dan indek tingkat kesukaran (TK) yang sekaligus terdapat interpretasi status soal (diterima, ditolak, diperbaiki).

Atas dasar alasan tersebut, akan dilakukan penelitian terhadap analisis butir soal tes sumatif mata pelajaran akuntansi 
keuangan yang dibuat oleh guru mata pelajaran Akuntansi Keuangan Kelas XI Akuntansi SMK Negeri 1 Yogyakarta menggunakan Program Microsoft Office Excel 2010.

\section{METODE PENELITIAN}

\section{Desain Penelitian}

Penelitian ini merupakan penelitian deskriptif kuantitatif untuk mencari informasi dan data yang dapat digunakan mendeskripsikan kualitas soal ujian akhir semester gasal mata pelajaran akuntansi keuangan kelas XI Akuntansi di SMK Negeri 1 Yogyakarta tahun ajaran 2013/2014. Pendekatan yang digunakan dalam penelitian adalah pendekatan kuantitatif dimana hasil penelitian diwujudkan dalam angka-angka dan dianalisis dengan menggunakan program Microsoft Office Excel 2010.

\section{Waktu dan Tempat Penelitian}

Penelitian ini dilakukan di kelas XI Akuntansi SMK Negeri 1 Yogyakarta yang beralamat di Jalan Kemetiran Kidul 35, Yogyakarta. Pengambilan data dilakukan pada bulan Desember 2013 setelah pelaksanaan ujian akhir semester gasal tahun ajaran 2013/2014.

\section{Subjek dan Objek Penelitian}

Subjek dalam penelitian ini adalah seluruh siswa kelas XI Akuntansi SMK Negeri 1 Yogyakarta Tahun Ajaran 2013/2014 yang terdiri dari 34 siswa kelas XI Ak1 dan 35 siswa kelas XI Ak2. Objek penelitian ini adalah Soal Ujian Akhir Semester Gasal Mata Pelajaran Akuntansi Keuangan Kelas XI Akuntansi SMK Negeri 1 Yogyakarta Tahun Ajaran 2013/2014 yang dibuat oleh guru mata pelajaran Akuntansi Keuangan.

\section{Prosedur Penelitian}

Kegiatan analisis butir soal ini menggunakan microsoft office excel 2010. Hasil perhitungan analisis yang berupa validitas, realibilitas, tingkat kesukaran, daya pembeda, pola sebaran jawaban akan dianalisis sehingga dapat diketahui soal yang baik, sedang, tidak baik/buruk. Soal yang baik disimpan di bank soal, soal yang sedang akan direvisi, soal yang tidak baik/buruk akan dibuang. Peneliti membantu guru dalam merevisi soal selanjutnya akan diuji cobakan kepada siswa serta melakukan analisis butir soal terhadap soal yang telah diujicobakan dan diharapkan bisa masuk dalam bank soal.

Prosedur dalam pengembangan sebuah bank soal, yaitu: perencanaan, pengembangan sistem (utamanya sistem basis data), pengumpulan butir soal, dan pengarsipan bank soal.

\section{Instrumen Penelitian}

Instrumen evaluasi yang digunakan dalam penelitian ini antara lain:

1. Daftar nama siswa

2. Soal Ujian Semester Gasal Mata Pelajaran Akuntansi Keuangan Kelas XI Kompetensi Keahlian Akuntansi

3. Kisi-kisi soal

4. Kunci jawaban dan jawaban seluruh siswa kelas XI Akuntansi

\section{Teknik Analisis Data}

Soal Ujian Akhir Semester Gasal Mata Pelajaran Akuntansi Keuangan Kelas XI Akuntansi SMK Negeri 1 Yogyakarta Tahun Ajaran 2013/2014 berbentuk pilihan ganda atau objektif dan soal uraian. Dimana soal pilihan ganda dan soal uraian dianalisis butir soal yaitu menggunakan program microsoft office excel 2010. Pada dasarnya microsoft office excel 2010 merupakan salah satu paket program aplikasi dari microsoft office 2010.

Data tersebut dianalisis berdasarkan:

\section{Validitas}

Validitas item bentuk pilihan ganda dapat dihitung menggunakan rumus korelasi poin biserial:

$$
\gamma_{p b i}=\frac{M_{p}-M_{t}}{S_{t}} \sqrt{\frac{p}{q}}
$$


Keterangan:

$\gamma_{p b i}=$ koefisien korelasi biserial

$M_{p}=$ rerata skor dari subjek yang menjawab benar bagi item yang dicari validitasnya

$M_{t} \quad$ =rerata skor total

$S_{t} \quad$ =standar deviasi dari skor total

$p \quad=$ proporsi peserta didik yang menjawab benar

$q \quad=(q=1-p)$

(Suharsimi, 2009: 79)

Indek korelasi point biserial $(\gamma p b i)$ yang diperoleh dari hasil penghitungan dikonsultasikan dengan $\mathrm{r}$ tabel pada taraf signifikansi 5\% sesuai dengan jumlah peserta didik yang diteliti.

Validitas item bentuk soal uraian dapat dihitung dengan rumus korelasi product moment adalah sebagai berikut:

$r_{\mathrm{xy}}=\frac{N \sum X Y-\left(\sum X\right)\left(\sum Y\right)}{\sqrt{\left\{N \sum X^{2}-\left(\sum X\right)^{2}\right\}\left\{N \sum Y^{2}-\left(\sum Y\right)^{2}\right\}}}$

Keterangan:

$\mathrm{r}_{\mathrm{xy}}=$ Koefisien korelasi antara $\mathrm{X}$ dengan $\mathrm{Y}$

$\mathrm{N}=$ Jumlah teste

$\sum X Y=$ Total perkalian skor item dan total

$\sum X=$ Jumlah skor butir soal

$\sum Y=$ Jumlah skor total

$\sum X^{2}=$ Jumlah kuadrat skor butir soal

$\sum Y^{2}=$ Jumlah kuadrat skor total

(Anas Sudijono, 2011: 181)

Indek korelasi product moment yang diperoleh dari hasil penghitungan dikonsultasikan dengan $\mathrm{r}$ tabel pada taraf signifikansi 5\% sesuai dengan jumlah peserta didik yang diteliti.

\section{Reliabilitas}

Reliabilitas untuk soal bentuk pilihan ganda dapat dihitung dengan rumus K-R 20 sebagai berikut:

$$
r_{11}=\left(\frac{n}{n-1}\right)\left(\frac{s^{2}-\Sigma p q}{s^{2}}\right)
$$

Keterangan:

$\mathrm{r}_{11}=$ reliabilitas tes secara keseluruhan

$\mathrm{p} \quad=$ proporsi subjek yang menjawab item dengan benar

$\mathrm{q}=$ proporsi subjek yang menjawab item dengan salah $(\mathrm{q}=1-\mathrm{p})$

$\sum \mathrm{pq}=$ jumlah hasil perkalian antara $\mathrm{p}$ dan $\mathrm{q}$

$\mathrm{n} \quad$ =banyaknya item

$\mathrm{S}$ =standar deviasi dari tes (standar deviasi adalah akar devians)

(Suharsimi, 2009: 100)

Reliabilitas untuk soal bentuk uraian dapat dihitung dengan rumus Alpha sebagai berikut:

$$
r_{11}=\left(\frac{n}{(n-1)}\right)\left(1-\frac{\sum \sigma_{i}^{2}}{\sigma_{t}^{2}}\right)
$$

Keterangan:

$\mathrm{r}_{11}=$ reliabilitas yang dicari

$\sum \sigma_{i}^{2}=$ jumlah varians skor tiap-tiap item

$\sigma_{t}^{2}=$ varians total

(Suharsimi, 2009: 109)

Pemberian interpretasi koefisien relibilitas tes pada umumnya digunakan patokan sebagai berikut:

a. Apabila $r_{11}$ sama dengan atau lebih besar daripada 0,70 berarti tes hasil belajar yang sedang diuji reliabilitasnya dinyatakan telah memiliki reliabilitas yang tinggi (reliable).

b. Apabila $r_{11}$ lebih kecil daripada 0,70 berarti tes hasil belajar yang sedang diuji reliabilitasnya dinyatakan belum memiliki relibilitas yang tinggi (un-reliable).

(Anas Sudijono, 2011: 209)

\section{Daya Pembeda}

Rumus menentukan indek diskriminasi adalah sebagai berikut: 


$$
D=\frac{B_{A}}{J_{A}}-\frac{B_{B}}{J_{B}}=P_{A}-P_{B}
$$

Keterangan:

$\mathrm{J}_{\mathrm{A}}$ =banyaknya peserta kelompok atas

$\mathrm{J}_{\mathrm{B}}=$ banyaknya peserta kelompok bawah

$\mathrm{B}_{\mathrm{A}}$ =banyaknya peserta kelompok atas yang menjawab

$\mathrm{B}_{\mathrm{B}}$ =banyaknya peserta kelompok bawah yang menjawab benar

$\mathrm{P}_{\mathrm{A}}=$ proporsi peserta kelompok atas yang menjawab benar

$\mathrm{P}_{\mathrm{B}}=$ proporsi peserta kelompok bawah yang menjawab benar

(Suharsimi, 2009: 201)

Interpretasi daya pembeda dapat diklasifikasikan sebagai berikut:

$$
\begin{aligned}
& 0,00-0,19=\text { jelek }(\text { poor }) \\
& 0,20-0,39=\text { cukup }(\text { satisfactory }) \\
& 0,40-0,69=\text { baik }(\text { good }) \\
& 0,70-1,00=\text { baik sekali }(\text { excellent })
\end{aligned}
$$

(Suharsimi, 2009: 218)

Angka interpretasi tersebut telah dimodifikasi karena terdapat kesamaan antara batas atas dan batas bawah.

\section{Tingkat Kesukaran}

Angka indek kesukaran item dapat diperoleh dengan menggunakan rumus sebagai berikut:

$$
P=\frac{B}{J S}
$$

Keterangan:

$P \quad=$ angka indek kesukaran item

$B$ =banyaknya testee yang dapat menjawab dengan betul terhadap butir item yang bersangkutan

IS =jumlah testee yang mengikuti tes hasil belajar

Kriteria indek kesukaran soal adalah sebagai berikut:

0,00-0,29 = soal kategori sukar

$0,30-0,69=$ soal kategori sedang

$0,70-1,00=$ soal kategori mudah

(Suharsimi, 2009: 210)
Angka interpretasi tersebut telah dimodifikasi karena angka yang terdapat dalam buku Suharsimi (2009: 210) antara batas akhir dan batas atas memiliki angka sama.

\section{Pola Sebaran Jawaban}

Pola sebaran jawaban diperoleh dengan menghitung banyaknya jawaban testee yang memilih jawaban a, b, c, d dan e atau tidak memilih sama sekali. Kualitas penggunaan pengecoh (distractor) baik atau tidak yang dapat diidentifikasi dengan rumus berikut:

$\%=\frac{\sum \text { Siswa memilih alternatif distractor }}{\sum \text { Siswa keselurwhan }} \times 100 \%$ berikut.

Kategori fungsi distraktor sebagai

a. Dikatakan sangat baik apabila distraktor pada soal berfungsi secara keseluruhan.

b. Dikatakan baik apabila distraktor pada soal tidak berfungsi satu alternatif.

c. Dikatakan cukup apabila distraktor pada soal tidak berfungsi dua alternatif.

d. Dikatakan kurang baik apabila distraktor pada soal tidak berfungsi tiga alternatif.

e. Dikatakan tidak baik apabila distraktor pada soal tidak berfungsi empat alternatif.

Hasil penghitungan kemampuan distraktor dapat dilihat dari proportion endorsing yang terdapat dalam hasil analisis.

Teknik analisis validitas, reliabilitas, daya pembeda, tingkat kesukaran soal, dan pola sebaran jawaban akan dianalisis menggunakan Microsoft Office Excel 2010 yang telah dimodifikasi dengan rumus-rumus yang dibutuhkan sesuai dengan kriteria kualitas soal. Penentuan kualitas soa antara soal yang berkualitas baik, cukup baik dan tidak baik didasarkan pada beberapa pertimbangan sebagai berikut: 
a. Butir soal dikatakan memiliki kualitas yang baik, apabila soal tersebut memenuhi empat kriteria yaitu validitas, tingkat kesukaran, daya pembeda dan pola sebaran jawaban.

b. Butir soal dikatakan memiliki kualitas yang cukup baik, apabila soal tersebut hanya memenuhi tiga dari empat kriteria.

c. Butir soal dikatakan memiliki kualitas yang tidak baik, apabila soal tersebut tidak memenuhi dua atau lebih kriteria butir soal yang baik.

\section{HASIL PENELITIAN DAN PEMBAHASAN}

Hasil yang diperoleh dari analisis terhadap soal Ujian Akhir Semester Gasal Mata Pelajaran Akuntansi Keuangan Kelas XI Kompetensi Keahlian Akuntansi SMK Negeri 1 Yogyakarta Tahun Ajaran 2013/2014 adalah sebagai berikut:

\section{Validitas}

Suatu tes dapat dikatakan valid apabila tes tersebut dapat mengukur objek yang seharusnya diukur. Pengujian validitas tes dapat dilakukan dengan dua cara yaitu dengan rasional (validitas isi) dan empiris (validitas item). Penentuan validitas rasional dilakukan penelusuran melalui segi isi (validitas isi). Validitas isi berkaitan dengan kemampuan tes dalam mengungkapkan konsep atau materi pembelajaran dievaluasi. Jika dilihat dari validitas tes, butir soal dikatakan memiliki validitas tinggi jika skor masing-masing butir soal memiliki kesejajaran arah dengan skor total. Dalam penelitian ini, validitas butir soal dihitung menggunakan rumus korelasi point biserial. Indek point biserial $(\gamma p b i)$ yang diperoleh dari hasil penghitungan dikonsultasikan ke $\mathrm{r}$ tabel pada taraf signifikansi 5\%. Hasil penelitian penelitian di SMK Negeri 1 Yogyakarta Kelas XI Kompetensi Keahlian Akuntansi yang telah diikuti sebesar 69 siswa sehingga $\mathrm{n}=69$, maka nilai $\mathrm{r}$ tabel menunjukkan angka 0,235 .

Hasil penelitian dan analisis terhadap validitas item soal Ujian Akhir Semester
Gasal Mata Pelajaran Akuntansi Keuangan Kelas XI Kompetensi Keahlian Akuntansi SMK Negeri 1 Yogyakarta Tahun Ajaran 2013/2014 berdasarkan pedoman bahwa $\gamma_{p b i} \geq 0,235$ berarti valid, sedangkan bila $\gamma_{p b i}<0,235$ berarti soal tersebut tidak valid.

Dalam penelitian ini, analisis validitas isi dilihat melalui kisi-kisi soal yang menunjukkan bahwa Soal Ujian Akhir Semester Gasal Mata Pelajaran Akuntansi Keuangan Kelas XI Kompetensi Keahlian Akuntansi SMK Negeri 1 Yogyakarta Tahun Ajaran 2013/2014 sudah sesuai dengan indikator pencapaian soal. Hal ini menunjukkan bahwa validitas isi Soal Ujian Akhir Semester Gasal Mata Pelajaran Akuntansi Keuangan Kelas XI Kompetensi Keahlian Akuntansi SMK Negeri 1 Yogyakarta Tahun Ajaran 2013/2014 termasuk dalam kategori soal yang memiliki validitas yang baik.

Hasil analisis validitas item menunjukkan bahwa soal Ujian Akhir Semester Gasal Mata Pelajaran Akuntansi Keuangan Kelas XI Kompetensi Keahlian Akuntansi Kelas XI Tahun Ajaran 2013/2014 butir soal pilihan ganda valid berjumlah 19 butir $(63,33 \%)$, sedangkan soal yang tidak valid berjumlah 11 butir $(36,67 \%)$. Bentuk soal uraian akan dinyatakan valid jika nilai korelasinya lebih dari 0,235 . Butir soal uraian yang valid yaitu $3(75 \%)$ butir, sedangkan soal yang tidak valid 1 butir (25\%). Butir soal yang tidak valid sebaiknya diperbaiki dan butir soal valid bisa langsung digunakan kembali dan dimasukkan dalam bank soal.

Berdasarkan uraian di atas, dapat disimpulkan bahwa soal Ujian Akhir Semester Gasal Mata Pelajaran Akuntansi Keuangan Kelas XI Kompetensi Keahlian Akuntansi Kelas XI Tahun Ajaran 2013/2014 termasuk soal baik berdasarkan validitasnya. Hal itu harus tetap dipertahankan dengan mengumpulkan soal baik ke dalam bank 
soal. Butir soal yang tidak valid sebaiknya diperbaiki dengan cara meningkatkan penguasaan teknik tentang penyusunan butir soal. Guru atau tim pembuat soal dapat meminta pendapat dari ahli untuk memantapkan validitas soal yang telah dibuat. Hal ini berarti validitas merupakan ciri-ciri tes penting.

\section{Reliabilitas}

Reliabilitas soal adalah tingkat konsistensi soal sehingga dapat dipercaya. Reliabilitas soal diukur dengan menggunakan rumus KR-20. Interpretasi koefisien reliabilitas $\left(\mathrm{r}_{11}\right)$ adalah apabila $r_{11}>0,70$ maka butir soal yang diujikan memiliki reliabilitas tinggi atau reliabel, tetapi apabila $\mathrm{r}_{11}<$ 0,70 maka butir soal yang diujikan memiliki reliabilitas rendah atau tidak reliabel.

Hasil penelitian menunjukkan bahwa soal Ujian Akhir Semester Gasal Mata Pelajaran Akuntansi Keuangan Kelas XI Kompetensi Keahlian Akuntansi SMK Negeri 1 Yogyakarta Tahun Ajaran 2013/2014 dengan bentuk soal pilihan ganda memiliki indeks reliabilitas sebesar 0,660, sedangkan bentuk soal uraian memiliki indeks reliabilitas sebesar 0,5. Hasil tersebut menunjukkan bahwa soal Ujian Akhir Semester Gasal Mata Pelajaran Akuntansi Keuangan Kelas XI Kompetensi Keahlian Akuntansi SMK Negeri 1 Yogyakarta Tahun Ajaran 2013/2014 termasuk dalam kategori tidak reliabel karena harga $r_{11}<0,70$ dan hasilnya akan tidak ajeg atau berubah jika diujikan kembali dalam kelompok yang sama. Hasil penelitian tersebut belum sesuai dengan kajian teori yang menyatakan bahwa salah satu persyaratan soal yang baik sebagai alat evaluasi adalah soal tersebut memiliki reliabilitas yang tinggi.

Berdasarkan uraian di atas dapat disimpulkan bahwa soal Ujian Akhir
Semester Gasal Mata Pelajaran Akuntansi Keuangan Kelas XI Kompetensi Keahlian Akuntansi SMK Negeri 1 Yogyakarta Tahun Ajaran 2013/2014 merupakan soal dengan reliabilitas yang rendah atau dapat dikatakan tidak reliabel.

\section{Tingkat Kesukaran}

Tingkat kesukaran butir soal adalah proporsi banyaknya siswa yang menjawab suatu soal dengan benar dengan jumlah seluruh peserta tes. Butir soal dapat dinyatakan sebagai butir soal yang baik apabila tidak terlalu sukar dan tidak terlalu mudah atau dengan kata lain harus termasuk dalam kategori sedang. Butir soal yang terlalu mudah akan menyebabkan siswa tidak termotivasi untuk mempertinggi usaha memecahkan soal tersebut. Sebaliknya soal yang terlalu sukar akan menyebabkan siswa menjadi putus asa dan tidak mempunyai semangat untuk mencoba lagi karena di luar jangkauannya. Butir soal yang baik adalah butir soal yang termasuk kategori sedang yaitu memiliki indeks kesukaran 0,31-0,70.

Berdasarkan hasil analisis yang dilakukan, diketahui bahwa butir soal Ujian Akhir Semester Gasal Mata Pelajaran Akuntansi Keuangan Kelas XI Kompetensi Keahlian Akuntansi SMK Negeri 1 Yogyakarta Tahun Ajaran 2013/2014 dengan diketahui bahwa 4 butir $(13,33 \%)$ soal kategori sukar, 9 butir soal $(30 \%)$ kategori sedang, dan 16 butir $(56,67 \%)$ kategori mudah, sedangkan untuk butir soal uraian 4 butir (100\%) tergolong kategori soal dengan tingkat kesulitan sedang.

Hasil penelitian tersebut telah sesuai dengan kajian teori yang menyatakan bahwa salah satu analisis yang harus dilakukan untuk mengetahui kualitas soal dikatakan baik sebagai alat evaluasi adalah analisis tingkat kesukaran. Butir soal yang termasuk 
kategori sedang harus tetap dipertahankan. Soal yang tergolong sukar harus diadakan perbaikan dengan mengganti soal dimana sebagian peserta didik mampu menjawab soal tersebut karena kemungkinan sebagian besar peserta didik telah memahami materi yang ditanyakan. Soal yang tergolong mudah harus diadakan perbaikan dengan mengganti kalimat yang lebih panjang dan kompleks sehingga menuntut peserta didik untuk lebih berpikir.

\section{Daya Pembeda}

Daya pembeda adalah kemampuan butir soal dimana skornya dapat membedakan siswa dari kelompok tinggi (menguasai materi) dengan siswa kelompok rendah (kurang menguasai materi). Berdasarkan hasil penelitian diketahui bahwa butir soal Ujian Akhir Semester Gasal Mata Pelajaran Akuntansi Keuangan Kelas XI Kompetensi Keahlian Akuntansi SMK Negeri 1 Yogyakarta Tahun Ajaran 2013/2014 bahwa butir soal pilihan ganda dengan daya pembeda jelek berjumlah 7 butir $(23,33 \%)$, cukup berjumlah 7 butir $(23,33 \%)$, baik berjumlah 10 butir $(33,33 \%)$, dan baik sekali berjumlah 6 butir (20\%). Bentuk soal uraian dengan daya pembeda jelek berjumlah 1 butir (25\%), cukup berjumlah $1(25 \%)$, dan baik sekali 2 butir (50\%).

Dari uraian di atas dapat disimpulkan bahwa soal Ujian Akhir Semester Gasal Mata Pelajaran Akuntansi Keuangan Kelas XI Kompetensi Keahlian Akuntansi SMK Negeri 1 Yogyakarta Tahun Ajaran 2013/2014 merupakan soal yang baik. Soal yang didominasi butir-butir soal dengan daya pembeda yang tidak berfungsi dengan baik menyebabkan peserta didik dengan kemampuan rendah dapat menjawab dengan benar, sedangkan peserta didik yang berkemampuan tinggi menjawab salah. Daya pembeda soal dapat digunakan untuk meningkatkan kualitas soal berdasarkan data empirik dan analisis butir. Indeks daya pembeda dapat menunjukkan apakah soal tersebut baik, harus direvisi, atau ditolak.

\section{Pola Sebaran Jawaban}

Pola sebaran jawaban diperoleh dengan menghitung banyaknya testee yang memilih jawaban a, b, c, d, e atau tidak memilih jawaban apapun. Hasil yang diperoleh dari seluruh lembar jawaban peserta didik diketahui bahwa seluruh peserta didik menjawab semua soal. Dari pola sebaran jawaban dapat ditentukan fungsi pengecoh (distractor). Sebuah pengecoh atau distractor dapat dikatakan berfungsi dengan baik apabila pengecoh tersebut mempunyai daya tarik yang besar bagi peserta tes yang kurang memahami konsep atau kurang mengusai materi. Suatu pengecoh dapat dikatakan berfungsi dengan baik apabila paling sedikit dipilih oleh $5 \%$ peserta tes.

Hasil penelitian menunjukkan bahwa 3 butir (10\%) memiliki pengecoh sangat baik, 10 butir $(33,33 \%)$ memiliki pengecoh baik, 11 butir $(36,67 \%)$ memiliki pengecoh cukup, 4 butir $(13,33 \%)$ memiliki pengecoh kurang baik, dan 2 butir $(6,67 \%)$ memiliki pengecoh tidak baik.

Besarnya persentase butir soal dengan kualitas pengecoh atau distractor yang kurang baik mengindikasikan bahwa pengecoh belum dapat berfungsi dengan baik, pengecoh terlalu mencolok, menyesatkan dan cenderung heterogen. Pengecoh tersebut tidak memiliki daya tarik yang besar bagi peserta tes yang kurang memahami konsep atau kurang menguasai materi. 
6. Analisis Butir Soal berdasarkan Validitas, Reliabilitas, Tingkat Kesukaran, Daya Pembeda dan Pola Sebaran Jawaban

Setelah dilakukan analisis menurut masing-masing kriteria, butirbutir soal kemudian dianalisis secara keseluruhan berdasarkan kriteria validitas, reliabilitas, tingkat kesukaran, daya pembeda dan pola sebaran jawaban untuk menentukan kualitas soal yang digunakan dalam Ujian Akhir Semester Gasal Mata Pelajaran Akuntansi Keuangan Kelas XI Kompetensi Keahlian Akuntansi SMK Negeri 1 Yogyakarta Tahun Ajaran 2013/2014. Penentuan kualitas soal antara soal yang berkualitas baik, cukup baik dan tidak baik didasarkan pada beberapa pertimbangan sebagai berikut:

a. Butir soal dikatakan memiliki kualitas yang baik, apabila soal tersebut memenuhi empat kriteria yaitu validitas, tingkat kesukaran, daya pembeda dan pola sebaran jawaban.

b. Butir soal dikatakan memiliki kualitas yang kurang baik, apabila soal tersebut memenuhi tiga kriteria yaitu validitas, tingkat kesukaran, daya pembeda dan pola sebaran jawaban.

c. Butir soal dikatakan tidak baik apabila dua atau lebih kriteria dari kriteria validitas, reliabilitas, indek daya pembeda, tingkat kesukaran, dan pola sebaran jawaban tidak baik.

Hasil keseluruhan analisis butir soal Ujian Akhir Semester Gasal Mata Pelajaran Akuntansi Keuangan Kelas XI Kompetensi Keahlian Akuntansi SMK Negeri 1 Yogyakarta Tahun Ajaran 2013/2014 berdasarkan validitas, reliabilitas, tingkat kesukaran, daya pembeda, dan pola sebaran adalah sebagai berikut:
Tabel 1. Hasil keseluruhan analisis butir soal Ujian Akhir Semester Gasal Bentuk Soal Pilihan Ganda Berdasarkan Validitas, Reliabilitas, Tingkat

\begin{tabular}{|c|c|c|c|c|}
\hline No. & $\begin{array}{c}\text { Kualitas } \\
\text { Soal }\end{array}$ & $\begin{array}{c}\text { Butir } \\
\text { Soal }\end{array}$ & Jumlah & $\begin{array}{c}\text { Persenta } \\
\text { se }\end{array}$ \\
\hline 1. & Baik & 1,4 & 2 & $50 \%$ \\
\hline 2. & $\begin{array}{c}\text { Kurang } \\
\text { Baik }\end{array}$ & - & - \\
\hline 3. & $\begin{array}{c}\text { Tidak } \\
\text { Baik }\end{array}$ & 2,3 & 2 & $50 \%$ \\
\hline
\end{tabular}

Kesukaran, Daya Pembeda Berdasarkan Pola Sebaran Jawaban.

Tabel 2.Hasil keseluruhan analisis butir soal Ujian Akhir Semester Gasal Mata Pelajaran Akuntansi Keuangan Kelas XI Kompetensi Keahlian Akuntansi SMK Negeri 1 Yogyakarta Tahun Ajaran 2013/2014 dengan Bentuk Soal Uraian Berdasarkan Validitas, Reliabilitas, Tingkat Kesukaran, Daya Pembeda

\begin{tabular}{|c|c|c|c|c|}
\hline No. & $\begin{array}{c}\text { Kualitas } \\
\text { Soal }\end{array}$ & $\begin{array}{c}\text { Butir } \\
\text { Soal }\end{array}$ & $\begin{array}{l}\text { Jum } \\
\text { lah }\end{array}$ & $\begin{array}{c}\text { Persen } \\
\text { tase }\end{array}$ \\
\hline 1. & Baik & $\begin{array}{c}5, \\
9,10, \\
15,23, \\
28,29\end{array}$ & 7 & $23,33 \%$ \\
\hline 2. & $\begin{array}{c}\text { Kurang } \\
\text { Baik }\end{array}$ & $\begin{array}{c}12,16, \\
17,18, \\
30\end{array}$ & 5 & $16,67 \%$ \\
\hline 3. & $\begin{array}{l}\text { Tidak } \\
\text { Baik }\end{array}$ & $\begin{array}{c}1,2,3, \\
4,6,7, \\
8,11, \\
13,14, \\
19,20, \\
21,22, \\
24,25, \\
26,27\end{array}$ & 18 & $60 \%$ \\
\hline
\end{tabular}


Berdasarkan tabel di atas dapat diketahui bahwa soal Ujian Akhir Semester Gasal Mata Pelajaran Akuntansi Keuangan Kelas XI Kompetensi Keahlian Akuntansi SMK Negeri 1 Yogyakarta Tahun Ajaran 2013/2014 memiliki kualitas yang tidak baik. Soal yang baik dapat dipertahankan dan digunakan kembali pada ujian berikutnya. Soal dengan kualitas tidak baik sebaiknya dibuang dan tidak digunakan lagi pada ujian berikutnya. Kegagalan butir soal disebabkan oleh tidak terpenuhinya salah satu parameter soal. Berikut ini penyebab kegagalan butir soal:

Tabel 3.Penyebab Kegagalan Butir Soal Ujian Akhir Semester Gasal Mata Pelajaran Akuntansi Keuangan Kelas XI Kompetensi Keahlian Akuntansi SMK Negeri 1 Yogyakarta Tahun Ajaran 2013/2014 dengan Bentuk Soal Pilihan Ganda

\begin{tabular}{|c|c|c|c|}
\hline $\begin{array}{c}\text { Penyebab } \\
\text { Kegagalan } \\
\text { Butir Soal }\end{array}$ & $\begin{array}{l}\text { Butir } \\
\text { Soal }\end{array}$ & Jumlah & Persentase \\
\hline Validitas & $\begin{array}{c}2,4,6,7 \\
8,11,13, \\
20,25, \\
27\end{array}$ & 10 & $33,33 \%$ \\
\hline $\begin{array}{l}\text { Tingkat } \\
\text { Kesukaran }\end{array}$ & $\begin{array}{c}1,2,3,7, \\
8,11,16, \\
17,18 \\
20,21, \\
22,24 \\
25,26\end{array}$ & 15 & $50 \%$ \\
\hline $\begin{array}{c}\text { Daya } \\
\text { Pembeda }\end{array}$ & $\begin{array}{c}2,4,6,7, \\
8,11,13, \\
19,20, \\
22,25, \\
27,30\end{array}$ & 13 & $43,33 \%$ \\
\hline $\begin{array}{c}\text { Pola } \\
\text { sebaran } \\
\text { jawaban }\end{array}$ & $\begin{array}{c}1,2,3,6, \\
7,8,11, \\
12,19, \\
20,21, \\
22,24, \\
25,26\end{array}$ & 15 & $50 \%$ \\
\hline
\end{tabular}

Tabel 4.Penyebab Kegagalan Butir Soal Ujian Akhir Semester Gasal Mata Pelajaran Akuntansi Keuangan Kelas XI Kompetensi Keahlian Akuntansi SMK Negeri 1 Yogyakarta Tahun Ajaran 2013/2014 dengan Bentuk Soal Uraian.

\begin{tabular}{|c|c|c|c|}
\hline $\begin{array}{c}\text { Penyebab } \\
\text { Kegagalan } \\
\text { Butir Soal }\end{array}$ & $\begin{array}{c}\text { Butir } \\
\text { Soal }\end{array}$ & Jumlah & Persentase \\
\hline Validitas & 3 & 0 & $0 \%$ \\
\hline $\begin{array}{c}\text { Tingkat } \\
\text { Kesukaran }\end{array}$ & - & 2 & $50 \%$ \\
\hline $\begin{array}{c}\text { Daya } \\
\text { Pembeda }\end{array}$ & 2,3 & 3 & $75 \%$ \\
\hline
\end{tabular}

Berdasarkan tabel di atas dapat disimpulkan bahwa penyebab kegagalan butir soal yang terbesar adalah tingkat kesukaran soal dan pola sebaran jawaban, ini berarti bahwa soal tersebut disajikan terlalu sukar atau terlalu mudah serta memiliki pola jawaban yang tidak baik yang berarti soal tersebut memiliki pengecoh yang tidak bekerja dengan baik. Soal yang memiliki pengecoh yang mencolok tidak menimbulkan ketertarikan peserta didik untuk memilih sehingga persebaran jawaban peserta didik terhadap setiap alternatif jawaban kurang dari $5 \%$.

Penyebab kegagalan yang kedua adalah daya pembeda, ini berarti soal tersebut tidak dapat membedakan siswa yang berkemampuan tinggi dengan siswa yang berkemampuan rendah. Penyebab kegagalan yang ketiga adalah validitas butir soal, ini berarti bahwa soal tersebut tidak memiliki kesesuaian 
atau kesejajaran arah dengan skor totalnya.

Butir soal yang kurang baik dan tidak baik dapat direvisi dengan melihat indikator penyebab kegagalannya. Butir soal yang baik dapat dimasukkan ke dalam bank soal dengan tetap menjaga kerahasiaan soal dan dapat digunakan kembali untuk ujian yang akan datang sehingga dapat mengurangi waktu yang diperlukan guru dalam proses pembuatan soal. Soal yang berkualitas dapat dihasilkan apabila guru menguasai teknik penyusunan soal. Hal ini dapat ditempuh dengan cara pengikuti pelatihan atau dengan membaca buku panduan penyusunan soal sehingga dapat membantu tugas guru dalam menganalisi butir soal.

\section{Tindak Lanjut}

Hasil analisis soal Ujian Akhir Semester Gasal Mata Pelajaran Akuntansi Keuangan Kelas XI Kompetensi Keahlian Akuntansi SMK Negeri 1 Yogyakarta Tahun Ajaran 2013/2014 menggunakan microsoft office excel 2010 dapat diketahui secara langsung status soalnya. Soal yang mempunyai status ditolak atau sebaiknya direvisi telah diperbaiki sesuai dengan kompetensi yang akan diukur. Soal yang telah diperbaiki kemudian diujicobakan kepada siswa yang mengikuti remidi sebanyak 41 peserta tes.

$$
\begin{aligned}
& \text { Jawaban siswa yang mengikuti } \\
& \text { remidi kemudian dianalisis } \\
& \text { menggunakan microsoft office excel } \\
& 2010 \text { sehingga akan mendapatkan status } \\
& \text { soal dapat diterima, diperbaiki atau di } \\
& \text { tolak. Soal yang telah direvisi dan } \\
& \text { mempunyai status soal dapat diterima } \\
& \text { maka akan dimasukkan ke bank soal } \\
& \text { dan dapat digunakan kembali dengan } \\
& \text { menjaga kerahasiannya. }
\end{aligned}
$$

\section{SIMPULAN DAN SARAN Simpulan}

Berdasarkan hasil analisis butir soal terhadap kualitas butir soal menunjukkan bahwa Soal Ujian Akhir Semester Gasal Mata Pelajaran Akuntansi Keuangan Kelas XI Kompetensi Keahlian Akuntansi SMK Negeri 1 Yogyakarta Tahun Ajaran 2013/2014 memiliki kualitas yang baik sebesar 23,33\%, kualitas yang kurang baik sebesar $16,67 \%$ dan kualitas yang tidak baik sebesar $60 \%$.

Kualitas butir soal didapatkan dari menganalisis beberapa segi analisis butir soal yang terdiri dari validitas, reliabilitas, tingkat kesukaran, daya pembeda dan pola sebaran jawaban terhadap Soal Ujian Akhir Semester Gasal Mata Pelajaran Akuntansi Keuangan Kelas XI Kompetensi Keahlian Akuntansi SMK Negeri 1 Yogyakarta Tahun Ajaran 2013/2014 maka dapat diperoleh kesimpulan yaitu sebagai berikut:

1. Ditinjau dari segi validitas, pada butir soal pilihan ganda valid 19 butir $(63,33 \%)$, soal yang tidak valid berjumlah 11 butir $(36,67 \%)$, sedangkan bentuk soal uraian valid 3 butir $(75 \%)$, sedangkan soal yang tidak valid 1 butir $(25 \%)$.

2. Ditinjau dari segi reliabilitas, pada bentuk soal pilihan ganda indeks reliabilitas menunjukkan angka 0,660, sedangkan bentuk soal uraian memiliki indeks reliabilitas sebesar 0,50. Hasil tersebut menunjukkan bahwa kedua bentuk soal baik soal pilihan ganda maupun soal uraian termasuk dalam kategori tidak reliabel karena harga $r_{11}$ $<0,70$.

3. Ditinjau dari tingkat kesukaran, pada bentuk soal pilihan ganda 4 butir $(13,33 \%)$ soal kategori sukar, 9 butir soal $(30 \%)$ kategori sedang, dan 16 butir $(56,67 \%)$ kategori mudah. Bentuk soal uraian 4 butir (100\%) tergolong kategori soal dengan tingkat kesulitan sedang.

4. Ditinjau dari daya pembeda, pada butir soal pilihan ganda dengan daya pembeda jelek berjumlah 7 butir 
(23,33\%), cukup berjumlah 7 butir $(23,33 \%)$, baik berjumlah 10 butir $(33,33 \%)$, dan baik sekali berjumlah 6 butir $(20 \%)$. Bentuk soal uraian dengan daya pembeda jelek berjumlah 1 butir (25\%), cukup berjumlah $1(25 \%)$, dan baik sekali 2 butir (50\%).

5. Ditinjau dari pola sebaran jawaban, pada bentuk soal pilihan ganda yang termasuk soal dengan pengecoh atau distractor yang berkualitas 3 butir (10\%) memiliki pengecoh sangat baik, 10 butir $(33,33 \%)$ memiliki pengecoh baik, 11 butir $(36,67 \%)$ memiliki pengecoh cukup, 4 butir $(13,33 \%)$ memiliki pengecoh kurang baik, dan 2 butir $(6,67 \%)$ memiliki pengecoh tidak baik.

Keseluruhan soal Ujian Akhir Semester Gasal Mata Pelajaran Akuntansi Keuangan Kelas XI Kompetensi Keahlian Akuntansi SMK Negeri 1 Yogyakarta Tahun Ajaran 2013/2014 termasuk soal yang tidak baik karena terdapat 18 butir soal $(60 \%)$ pada bentuk soal pilihan ganda dan 2 butir soal $(50 \%)$ pada bentuk soal uraian yang tidak memenuhi syarat validitas, reliabilitas, daya pembeda, tingkat kesukaran, dan pola sebaran jawaban.

\section{Saran}

Berdasarkan hasil analisis terhadap kualitas butir soal yang terdiri dari validitas, reliabilitas, tingkat kesukaran, daya pembeda dan efektivitas pengecoh atau distractor secara bersama-sama terhadap Soal Ujian Akhir Semester Gasal Mata Pelajaran Akuntansi Keuangan Kelas XI Kompetensi Keahlian Akuntansi SMK Negeri 1 Yogyakarta Tahun Ajaran 2013/2014 maka saran yang dapat diajukan yaitu sebagai berikut:

1. Soal baik dimasukkan ke dalam bank soal atau disimpan untuk dipakai kembali pada ulangan selanjutnya dengan tetap menjaga kerahasiaan soal tersebut.
2. Soal dengan kategori kurang baik dan tidak baik sebaiknya dilakukan revisi sesuai dengan indikator penyebab kegagalannya sehingga menjadi soal yang baik. Cara yang dapat dilakukan untuk merevisi antara lain dengan menyamakan isi soal dengan indikator yang sesuai dengan materi atau dengan mengganti pengecoh agar dapat menimbulkan daya tarik bagi peserta tes untuk memilihnya.

3. Proporsi soal yang terlalu banyak berkualitas mudah, sebaiknya dikurangi agar lebih bisa membedakan siswa yang berkemampuan tinggi dan berkemampuan rendah, yang mana akan lebih menuntut siswa untuk berpikir. Hal ini bisa dapat dilakukan dengan cara membuat proporsi soal mudah, sedang, sulit terlebih dahulu sebelum membuat soal.

4. Guru lebih meningkatkan pemahaman serta kemampuannya dalam menyusun soal dan menganalisis butir soal karena dapat membantu dalam mengetahui kualitas butir soal sehingga soal yang diujikan terdiri dari soal-soal yang memenuhi syarat validitas, reliabilitas, tingkat kesukaran, daya pembeda, dan pola sebaran jawaban.

\section{DAFTAR PUSTAKA}

Anas Sudijono. (2011). Pengantar Evaluasi Pendidikan. Jakarta: PT Raja Grafindo Persada

Arif Rohman. (2009). Memahami Pendidikan Ilmu Pendidikan. Yogyakarta : LaksBang Mediatama Yogyakarta

Costagliola, G dan Fuccella, V. (2009). "A Rule-Based System for Test Quality Improvement". International Journal of Distance Education Technologies. 7(II). Hlm. 63-82 
Daryanto. (2008). Evaluasi Pendidikan. Jakarta: PT Rineka Cipta

Kunandar. (2008). Guru Profesional. Jakarta: PT Raja Grafindo Persada

Nana Sudjana. (2012). Penilaian Hasil Proses Belajar Mengajar. Bandung: PT Remaja Rosdakarya

Ngware, M dan Ndirango, M. (2005). “An improvement in instructional: can evaluation of theaching effectiveness make a difference?. International Journal of Quality Assurance in Education. 13(III). Hlm. 183

Slameto. (2001). Evaluasi Pendidikan. Jakarta: Bumi Aksara

Suharsimi Arikunto. (2009). Dasar-Dasar Evaluasi Pendidikan. Jakarta: Bumi Aksara

Sumarna Surapranata. (2006). Panduan Penulisan Tes Tertulis. Bandung: PT Remaja Rosdakarya

Zainal Arifin. (2013). Evaluasi Pembelajaran. Bandung: PT Remaja Rosdakarya 